\title{
Subjective Involvement in Record Photography
}

\author{
Xiaozhou Li \\ School of Art and Design \\ Xi'an University of Technology \\ Xi'an, China
}

\begin{abstract}
The depth of subject matter of record photography is based on the principle of "from individual to group and from special to universal", and it mainly conducts intensive study of the relationship between people, people and society. Such evaluation on the basis of reality can be reflected in the photographer's cognition of society through his theme selection. Record is a means for making the visual transmission process of photography more real, but it can be reflected in different levels of reality: it can be the reality witnessed by the bystanders; or the reality of a participant; even the reality of own experience. The final property of reality will produce different results depending on the identity of the photographer and the degree of involvement in the event. This paper mainly explains the most central authenticity of record photography and record works generated in different times, summarizes the means of subjective control, and deeply discusses the authenticity of record photography under subjective control.
\end{abstract}

\section{Keywords—record photography; subjective involvement}

\section{INTRODUCTION}

"Documentary photography" was introduced into China in the 1980s and still in use today. Because at that time China's photography theory system was just established soon, coupled with the embarrassing situation that photography served politics for a long time, the word "documentary" cannot cover its essence. Because in the film and television field, "documentary photography" has almost the same position and creative ideas with "record film", so the translated title of "documentary film" seems more accurate and proper. And in the subsequent development process, more and more people are suspicious of "documentary", thinking that "record" is more accurate than "documentary". Under the influence of contemporary art, photography became the most direct and quickest way to promote artistic concept, and the development of photography itself was more diversified. The new cognition of photography continues to attack the original camp of "documentary photography". In this situation, photography, taking record as a means, appears in the public view with a new look.

In the course of development of record photography, the onlooking and involvement at the time of shooting also develops accompanied by record. The essence of this problem is the choice and tendency of the photographer in truthfully restoring the event and subjective intention judgment. It seems that record photography gives an impression of objective reduction of events from the embryonic stage, but pure objective in photography does not exist. The photographer operates camera to intercept a moment of the real scene is a subjective screening process itself, even though it restores the event objectively to the largest extent, but in essence it is still a subjective presentation process. So the subjective involvement in the record photography is inevitable, only the involvement is different. With the development of record photography itself and the gradual improvement of understanding over it by human, the subjective involvement in record photography is gradually recognized, and even become a means of expression and style of some photographers, and from another point of view, it also expands the ways of expression of record photography.

\section{INTERVENING IN PRIVATE SPACE}

Most of the subjects involved in record photography are in the open air, mainly because the photographic material of camera has a direct connection to the light, and even today, it is still a large limitation on photography, as clear image cannot be obtained without sufficient light. In order to break this limit, some photographers chose flashlight in order to shoot in the dark light, for example, the famous photographer Wiki uses such a means. But the use of flashlight will give the picture an effect completely different with that of natural light, making the picture appears to be too stiff, so most photographers are not willing to accept this way. On the other hand, most people do not want their private life to be photographed unless they are familiar with the photographer or the photographer is very trustworthy. To shoot in a private space equals to entering a private territory, and people have precaution in the mind within a short period of time. Long time of communication with the people is needed to make him/her put down the grudge and forget your existence, so as to present the truest side.

With respect to the series description of private space, it can be traced back to the aforementioned British photographer Bill Brandt. He took the photos by knocking on the doors of all kinds of family. There are luxury living rooms of the rich and small rooms of the poor in the photos, and the photographed characters show a very natural side in the private space, as if having forgot his existence. Bill Brandt used the class in the sociological system as the starting point for shooting. In 1936, Brandt published The English At Home, establishing his position in the record photography history. 
The exploration of domestic record photography in private space is obviously later than that of the Western countries, which is directly related to the late start of development of record photography in China. In China, the photographer who shoots private places earlier is undoubtedly Henan photographer Jiang Jian. He began to shoot the environment and furnishings of rural families in the Central Plains in the late 1980 s, although no characters appear in the picture, it is full of life breath. After that, Jiang Jian extended based on the works of "The Scene", and continued to create with "Master" as the title. Color film is adopted in this work, and the subject is still the rural families in the Central Plains. In the picture, there are not only the rural family furnishings, but also the owner of the family. From the traditional rural family furnishings to the mud wall plastered with the Hong Kong and Taiwan star posters, revealing the changes in Chinese rural areas. In the $21 \mathrm{st}$ century, Jiang Jian still uses the means of involvement in private space to create, shooting the theme of "Chinese in Paris," recording the condition of overseas Chinese, the special group. Jiang Jian's use of private space intervention to create series of photography reflects the value of involvement in the record photography, and it is a case of record photography in the diversified development of China.

Another Henan photographer Su Sheng creates a group of "Chinese-style Children" with the same means of private space involvement. This group of works reflects the social problems brought about by the national policy of "family planning" in China in the 1980s. The author himself grows up under this national policy, without brothers and sisters, he feels very lonely. This work takes children as subjects, showing the only child stays lonely in his/her own empty room, dazing alone while facing their beloved toys and looking out the window alone.

The involvement means of private space gradually increased with the development of record photography. Such type of record photography can reveal the most relaxed nature of the characters in their most familiar places, which is generated by people's curiosity about other's privacy when the society develops to a certain degree, and the important evidence of record photography's gradual subjectivisation and individualization.

\section{INTERGROUP INVOLVEMENT}

To understand one thing, the real understanding cannot be reached unless to experience it; to learning about a person, it is best to live or work with him/her; to know a group, it is the best to become a member of them. What is actually said here is the concept of internal group and external group. In photography, this concept is often mentioned by people, but also a symbol of the photographer to define his position. Such position is also formed gradually in the selfimprovement of record recorded photography, playing a very crucial role for the healthy development of record photography. In order to understand things in depth, the nature is often cannot be reached from the spectator's perspective, and sometimes it is necessary to be involved in the group.
In the 1960s, American photographer Danny Leon bought a motorcycle to join the "Devil Angel" club composed of hippies in order to shoot the special group of motorcyclists. He spent two years with them day and night, photographed their racing, repairing and fighting, and published "driver" in 1968. This way belongs to the intergroup involvement, making the photographer a party of the event from the spectator, to make the work more convincing.

The more representative one of photography method using intergroup involvement is American photographer Larry Clark, who is also a representative of the private record photography. He photographed the themes of American teenagers, such as violence, drugs and sex. He photographed the pictures of his friends who live in his homeland Wisconsin in the late 1960s and early 1970s. These photos describe the adolescents' rebellious acts in pursuit of freedom, such as taking drugs, sexual abuse, playing with pistols and so on. In the narration, Larry Clark also described he and his friends were arrested because of injection of drugs, alcoholism, prostitution and brawl, which is an self-care of people within the same group, also marks that the creation of record photography has transferred to a party's experience from the representation of spectator, meaning that the perspective in the work rises from the third person to the first person. The private group involvement in record photography is telling the story of his own, and the image taken in this position is more real than that from a spectator's view.

With the development of the times, the care for human nature and the reality is also constantly changing. With the influence of artistic trends and various new media, the record of a spectator can no longer be able to meet people's curiosity for deep exploration of things. Photographer also enriches the development of record photography with different involvement ways, and record photography has become a long lasting visual presentation style with its own uniqueness.

\section{CONCLUSION}

The value of the record photography wins great popular support. The current photographers have a considerable ability to grasp the operation modes of record photography, and begin to seek a breakthrough in terms of theme selection and means. Social development will not only provide photographers with a variety of photographic resources, but also greatly improve the reader's ability to accept the record photography. Record photography will enter into a diversified period of development, photographers' awareness of based on individual and facing the public will be increasingly strengthened, the contribution to social and cultural construction will be substantial, and the theme and means will be increasingly diversified with the social changes, and the authenticity of photography will make new demands on record photography in new period. 


\section{REFERENCES}

[1] Li Wenfang. A World History of Photography [M]. Liaoning Fine Arts Publishing House, 2007.08

[2] History of Photography [M]. Chongqing Publishing House, 2008.9

[3] Lin Lu. History of Photographic Thoughts [M]. Zhejiang Photography Publishing House, 2008.03

[4] Sun Jingtao. Documentary Photography Style and Exploration [M]. Shandong Pictorial Publisher House, 2004.06

[5] Su Zhigang. Dialogue between Mirror [M].Jilin Photography Publishing House, 2003.06

[6] Gu Zheng. No Truth behind Truth [M]. China Worker Publishing House, 2002.05. 